\title{
Legal Issues in the Management of Patients' Records in Tertiary Hospitals in Nigeria
}

\author{
Kayode Sunday Osundina1* Joseph Adeniyi Kolawole ${ }^{2}$ and \\ Joshua Adediji Abolaji \\ ${ }^{1}$ Lecturer, Health Information Management Department, Lead City University Faculity of Sciences, Oyo State \\ Nigeria. \\ 2,3 Senior Librarian, Joseph Ayo Babalola University, Ikeji Arakeji Osun State, Nigeria.
}

\begin{abstract}
This study investigated the legal practices practiced by records managers in the management of patients' records in tertiary hospitals in Nigeria, so as to know how legal issues influenced the management of patients' records in Nigeria tertiary hospitals. The correlation research design was adopted for the study. The population consisted of all the 282 records managers in the 10 tertiary hospitals in South-West, Nigeria. Data generated through questionnaire were analysed using descriptive statistics, simple correlation analysis at 0.05 alpha level. Findings revealed that record managers paid much attention to records creation, records storage and considerable actions in health records departments. Finding also deduced that legal considerations existed in tertiary hospitals in South-West, Nigeria. The study concluded that there was a significant positive relationship between records managers' legal issues and the management of patients' records in tertiary hospitals in South-West, Nigeria $(r=.418, N=230, P<.0 .05)$. The study therefore recommended that federal government should promulgate law on management of patients' records that will cut across the federal, state and local government so as to provide uniform practice and enhance good standard of records management practice. Finally, violators of rules concerning patients' records and rights of privacy abuses should be made to face the wrath of the law, so as to serve as deterrent to others.
\end{abstract}

Keywords: Electronic Health Records, Legal issues, Patients' Records, Records Management, Tertiary hospitals,

\section{Introduction}

The recent complexity of modern medical and surgical treatments existing in tertiary hospitals in Nigeria requires accurate and adequate patients' records, as documentary evidence of the care and treatment which the patient received in the hospital.American Health Information Management Association and Health Information Management Association (AHIMA) of Nigeria professional (2011) views records management in the health care industry as a special programme in health information management which involves not only maintaining patient files, but also coding the files to reflect the diagnoses and operations of the conditions affecting the patients. Records management is a discipline which utilizes an administrative system to direct and control the creation, distribution, filing, retention, storage, and disposal of records in a way that is administratively and legally sound while at the same time serving the operational needs of the trust and preserving an appropriate historical record (North East London Foundation Trust, 2011). In developing and implementing policies, procedures and guidelines areneeded for effective filing, storage and to make available both physical and electronic health record for patient treatment in the hospital, in accordance with the State and Federal laws, will improve the availability and security of patients' information and guarantee continuity of patient care (Huffman, 2001).

The advent of information technology (IT) devices in the processing and handling of patients' information has raised several legal issues in the management of patients' records in the hospitals. In fact, most of the legal issues of concern are as a result of the arrival and use of information technology devices. Recognizing the federal and state laws, guidelines and policies, he statutory laws and regulations guiing the release of patient information, is necessary in order to protect the confidentiality, integrity and privacy of patient records and to avoid liability and ensure that only authorised agent with a written consent from the patient is given the permission to view or have access to a patient's record (Cohen, 2004).Information in patients' record is confidential because it is held in trust for the patient: the relationship between patient and physician is special and their communication should be protected from disclosure. This is supported by the code of ethics of health records management and federal and state laws of Nigeria Cap 16 and Decree 39 of 1989. The decree establishing Health Records Officers Registration Board of Nigeria was printed and published by the Federal Republic of Nigeria Official Gazette N0. 71 Vol.76 of $11^{\text {th }}$ December 1989. It was promulgated to regulate the 
practice and training of Health Records Officers in Nigeria and also to institute professional discipline of members for unprofessional conducts.

An inactive record is a record that is no longer needed to conduct current business but is being preserved until it meets the end of its retention period. These records may hold business, legal, fiscal or historical value to the organization in future and they are required to be maintained for short or permanent duration. Lack of effective retention policy and disposal schedules in the storing, filing and disposal of patient's record may contributes to poor management of patient medical records in the hospital. Therefore, the proper management of patients' records requires that adequate attention be paid to legal concerns. A law is defined as a rule of conduct or action prescribed or formally recognized as binding or enforced by a controlling authority, such as local, state, and federal governments. Legal considerations also tend to be more affected by historical precedent, matters of definition, issues related to detecting ability and enforceability, and evolution of new circumstances that are ethical ones (Goodman, 2010).

In Nigeria, federal agencies and other medical practices such as Health Records Officers Registration Board of Nigeria; Nigeria Medical Council, Nurses and Midwifery Council of Nigeria, etc regulates the practice of health records management and other medical practices in Nigeria. These are the accrediting agencies that are given power by the federal statutes to make rules concerning good standard of health care training/practices in Nigeria. In the same way, State legislatures such as State Hospitals Management Board makes rules regulating health care practices including health records management in the areas of disclosure of information, and confidentiality of patients records (Maduewesi, 2004).Authorisation from the patient or his authorised representative is crucial to avoid divulging patient information to a wrong party that may use the information against the patient's consent.(Benjamin, 2010). Patients' records may be requested for insurance purposes, medical research, and continuity of care or as evidence in case of litigation. Strict adherence to legal rules and principles will prevent illegal practices. But, failure of the records managers to observe the legal rules and principles that ensure right conduct based on the medical oaths and rules that prescribe medical professionals' character, motives and duties which should guide the health professionals in their dealings with their patients, may result to unethical practices. It is the responsibility of records managers to comply with the legal instruments in order to protect the rights of the patient and thereby contribute to legal justice.

Illegal use of patient records, inaccurate record keeping and other forms of invasion of patients' fundamental human rights which are regarded as illegal issues that may have negative impact and grave consequences on the management of patients records. In spite of these attendant serious concerns, it is not immediately clear the extent to which health records managers' in Nigeria's tertiary hospitals pay attention to legal issues in their management of patients' records. This study, therefore, examined how legal issues influenced the management of patients' records' by records managers in tertiary hospitals in South-West Nigeria.

\section{Literature}

This section presents the review of literature and extracted past works, ideas and empirical studies of many authors on legal issues in the management of patients' records in tertiary hospitals. Thus, the review describes, evaluates and summarises the literature relevant to this study and were discussed under the following sub-headings:

\subsection{Management of Patients' Records}

Patient record begins at birth and ends at death. It is a collection of information from multiple sources with a wide variety of uses. It includes data from the individual patient record as well as aggregate data on patient population, such as clinical and non-clinical data, epidemiological data, demographic data, research data, reference data and coded data. Therefore health records manager must ensure the availability of high quality data and information to support the healthcare industry (Institute of Medicine 2007). Medical information is the life blood of the health care delivery system, the patients' records in manual or automated form contains medical information that describes all aspects of patient care. It is an essential tool in running the day - to - day health services rendered to patients in the hospital (Hufman 2001).

Record is a written account of facts, events, official facts (as public records) written down at the time they occurred and stored or preserved in writing as authentic evidence, set down in writing for future references, preserved for use by writing or in other ways e.g. on disc, and other electronic media. Health record is a clear, concise and accurate history of a patient's life and illness written from medical point of view. It is the primary source of medical statistics and clinic materials for the present and future researchers (Akanji 2010). It is a device used for recording the significant characteristics of a patient and his illness and the events occurring in the course of professional care for the purpose of providing the best medical care to the patient. It is useful for undertaking teaching, research, study and treatment, appraisal of medical practice and legal requirement. Before a patient's record can be used for the above mentioned purpose, it has to be complete, accurate, and adequate; 
therefore the health records must contain sufficient information written in sequence of events to justify the diagnosis, warrant treatment and end result (Benjamin 2010).

Records management includes the process of identification, classification and retrieval, storage and protection, receipt and transmission, retention and disposal or preservation of records of an organization (Rhoard 1983). Relevant and accurate public records are essential to preserving the rule of law and demonstrating fair, equal and constant treatment of citizens. Without access to records the public does not have the evidence needed to hold officials accountable or to insist on the prosecution of corruption and fraud. However it is critical when considering access laws to develop an effective records infrastructure to prevent manipulation, deletion, and loss of records (Millar 2003). Records provide a reliable, legally veritable source of evidence of decisions and actions; they are document compliance or non compliance with laws, rules, and procedures. Records management issues should therefore be addressed by a legislation because without a substantial records management in place all legislative laws would be worthless and sound records management principles must be adhered to, if governments are to successfully implement the requirements of access laws (Mnjaina 2003).

AHIMA (2011) asserts that records management in the health care industry is a special program in health information management which involves not only creation, maintenance and disposal of patient files, but also coding the files to reflect the diagnoses and surgical operations of the conditions suffered by patients. Record is a documentary evidence of the day to day activities of an organization be it private or public, records include all the documents that an organization receives or creates during the cause of her administrative or executive transaction. Records of the organization are the memory of the organization; any organization that does not keep its records suffers from amnesia and would lose its identity and integrity. It is necessary to manage records in a meaningful way so that they can be accessed and used in the course of daily business transactions.

\subsection{Legal Issues in Patients' Records Management}

The health records management professionals must possess the knowledge of and understand legal processes, both civil and criminal processes. Civil cases involve relations between individuals, corporations, government entities, and other organizations. The remedy for civil wrong is monetary in nature while criminal cases addresses crimes that are wrongful acts against public health, safety and welfare which attracts punishment for those people violating the law(Pozgar, 2007). Joint Commission on Accreditation (2008) reveals that the health records managers' must understand all the regulations and statutes that affect the creation and maintenance of patients' records and their content as approved for the health care organization. It is also important that the records manager should heed to the requirement of agencies and laws that regulate hospitals. Because the health care industries including hospitals are regulated by all levels of government, accrediting agencies, and professionals ethics.Hughes (2002), in his own wisdom, states that hospitals cannot operate without a license and any hospital that violates the standard of care may lose their licenses or be penalized. He states further that the privacy Act 1974 states that patients have the right to learn what information has been collected about them, view and have a copy of that information and maintain limited control over the disclosure of that information to other persons or entities. Therefore any disclosure of information by the hospital without the written consent of the patient can lead to violation of patient privacy and may be penalized.

Rinehart- Thompson et al (2008) assert that patients' records are business records that serve as testimony in legal proceedings. The legal standard that controls whether a record is admissible in court apply regardless of whether the patients' record is paper or electronic. Such standard includes trustworthiness of the information recorded and potential evidential value. He explained further that state and federal laws regulations licensure requirement and accrediting body as standard, defining patients' record content, maintenance and documentation are necessary as legal health records, because inaccurate and incomplete patients' records show that no activity occurs to patients if actionable in the court.Pozgar (2007) in his opinion describes the comprehensive drug abuse prevention and control Act 1970 which controls the use of narcotics, stimulant, depressants and hallucinogens. The act also affects the dispensing and administration of these specific categories and wrong dispensing of drugs to patient. Pharmacists must be versed in this law and how it interacts with state licensing and regulatory laws and accrediting standards to ascertain that an order in the health record satisfies the requirement for a lawful order. The practitioner signing the prescription and the dispensed drug or the order in the patients' records / prescription sheet will be liable for wrongful prescription or drug dispensation.

Health Insurance Portability and Accountability Act (HIPPA 1996) Standards with Federal and State laws are enacted to protect the patients' documentation in the paper and electronic health information systems include many sacred secret stories, on behalf of the patients and the consumers served by the health care system; that is health care team, the peers, colleagues, the public or other stakeholders who seek access to patient and consumer information. In the healthcare system, patients' records contain documented decision making process on patients health conditions during hospitalization and many people want access to that information (AHIMA, 
2004). Pozgar (2007) asserts that health care industry is involved most often in civil cases and less often in criminal cases. Torts and contracts are the most typical civil legal actions that affect the healthcare industry. Torts is an action brought when one party believes that another party caused harm through wrongful conduct and the party bringing the action seeks compensation for that harm and also to discourage the wrongdoer from committing further wrongful acts. He further stressed that when a person does not act the way a reasonably prudent person would act under the same circumstances generally that is negligence which is careless conduct that is outside the accepted standard of care. Standard of care is defined as what an individual is expected to do or not do in a given situation; these are established by professional association; policies, federal and state laws or regulations or by practice. The health professional can be found negligent when he or she has failed to guard against a risk that he or she knows could happen or that a particular behaviour would place others in unreasonable danger.

\subsection{Electronic Health Records Management}

Institute of Medicine (2001) defines the computer based patient record as an electronic patient record that resides in a system specifically designed to support users by providing accessibility to complete and accurate data; it also provides alerts, reminders ,clinical decision support systems and links to medical knowledge. Therefore, Hughes (2002), Rhodes (2000), AHIMA (2002) observe that protecting privacy in an electronic environment is becoming increasingly concern about the loss of privacy and their inability to control the dissemination of records about them. As patients become more aware of the misuse of records they may become reluctant to share information with their health care team which may result in difficulty in providing information to researchers, insurers, government and other stake holders who legitimately need to access patients' records.

However, Dick and Steen (2001) describe electronic health record as a system consisting of electronically stored information about an individual's lifetime health status and healthcare. It replaces the paper medical record as the primary record of care, meeting all clinical, legal andadministrative requirement. It provides reminders and alerts linkage with medical knowledge sources for decision support and data for outcomes research and improved management of health care delivery.The nation alliance for health information technology (2008) agree that electronic health record is an electronic record of patients' related information on an individual that can be created, gathered, managed and consulted by authorised clinicians and staff within and across more than one healthcare organization. Dick et al (2007) affirm that electronic health record is a set of component that form the mechanism by which patient records are created, used, stored and retrieved; it includes people, data, rules and procedures, processing and storage devices, communication and support facilities.

Rotch (2003) assert that information and communication technologies (ICT) have been recognized in the past decades as an essential tool for the scientific, economic, and social development of a country. In the health sector these technologies have proven to be a significant factor for an effective and comprehensive planning, management, and estimation of health care. The increased development and use of these technologies in health care delivery systems in the industrialized countries led to an improvement of the quality of services, security as well as to cost reduction for patients. However in developing countries, the situation still looks different at present. The observation of recent progress in some Asian countries such as India confirms the importance of the integration of ICT in health systems of developing countries. Despite this fact, there are hardly hospitals and health centres in developing countries -especially in Sub-Saharan Africa- with ICT-Infrastructure ready for accessibility to information systems.

Bloomrosen (2006) in his own view states that the advent of electronic information system has presented complex challenges with regard to records integrity and information security and the protection of information in e- health systems, exchanging information with and across jurisdiction, executing technical and clinical services contract, handling release of information, implementing and managing the health applications. Therefore as patients' records becomes computerised and health care facilities began to link various health information systems, the temptation or risk increased to sacrifice privacy as data integrity for the sake of business efficiency and timely access to information. Therefore, Rob Coronel (2009) challenge the records managers to understand database management design and management so as to participate actively with the information system. Database management system is a collection of computer software that manages and controls access to the data in the database. Pratt and Adam ski (2008) believe that today's healthcare information system are generally built on an underlying database structure and can be found in computer applications ranging from an enterprise wide - clinical data repository to a small desktop application designed to track delinquent signatures on patients' records.

Electronic clinical documentation systems enhance the value of EHRs by providing electronic capture of clinical notes; patient assessments; and clinical reports, such as medication administration records (MAR). As with Computerized Physician Order Entry components, successful implementation of a clinical documentation system must coincide with a workflow redesign and buy-in from all the stakeholders in order to realise clinical 
benefits.Examples of clinical documentation that can be automated include:Physician, nurse, and other clinician notes, flow sheets (vital signs, input and output), problem lists, peri-operative notes, discharge summaries, transcription document management, medical records abstracts, advance directives or living wills, durable powers of attorney for healthcare decisions, consents (procedural), patients 'record/chart tracking, releases of information (including authorizations), staff credentialing/staff qualification and appointments documentation, chart deficiency tracking and utilization management (Haugh, 2005).

\subsection{Theoretical Framework}

\subsubsection{The Privacy Protection Model}

The components of Yuan's model of privacy protection (2001) are explained in the context of this study. These components are: privacy subject, information collector, privacy violator and privacy protector. The Privacy Subject according to Yuan (2001) is the individual or organization that has a concern and legal rights to control the sharing of information about itself. For instance a patient is a privacy subject who has a concern and the right to control the sharing of her health information in that organization. She may be willing to share her health information with a medical doctor but may not want other people to access it without her consent. Similarly an online customer may not want a company to sell her purchase details to others. Yuan (2001) recognizes Information collector as the fact that information collector is an individual or organization such as (the records managers) that collects private information such as patient's personal information from privacy subjects. Therefore information collection is necessary to provide patients with services: for instance, the government collects information about citizens' income and tax payments, banks collect information about clients' payment transactions and hospitals collect patient information about health care. Once the private information is gathered, it is the collector's legal responsibility to maintain its security and privacy. Hospitals hold a large amount of information about their patients, much of their documentation is still paper-based and is not electronically shared but sharing of patients' information will be a major issue as soon as patient records become computerized. Privacy Violator - the model describes the privacy violator as an individual or organization that illegally or unethically collects, distributes and uses private information without the consent of the patient. For example when hospitals send patients' information with his e-mail address for publication or for on-line promotion, both hospitals and the organization become privacy violators. The model further stresses that the serious violator is the hacker who breaks in and steals personal information to commit fraud. Privacy Protector- individual or organization that aims to protect the privacy of patients. The aims to protect the privacy of patients includes government legislations, policies, professional ethical rules and self-regulatory agencies that provide information, services and tools to enhance privacy awareness and protection.

\subsubsection{Records Life Cycle}

The records life cycle model sees records passing through stages until they eventually die, except for the chosen ones that are reincarnated as archive. This is supported by Schellenberg (1998); Sheppard and Yeo (2003) that, records are not static, but have a life similar to a biological organisms therefore, the management of patients' records involves the stages of records life cycle which include records creation, active records, semi active records/inactive records, final disposition, archiving and destruction, this shows that records are born or created for a particular purpose and when the records are no longer needed by the organization after a long period of active use they are placed in the inactive records for final disposition. This model was originated by Schellenberg"s thought in 1956. He made a clear distinction between records management and archival preservation of records. Records are created and actively used in relation to the purpose of their creation, when the records are no longer useful, a decision is taken whether the records should be preserved or disposed. Records management life cycle has been useful in promoting a sense of order, a systematic approach to the overall management of recorded information (Agrell, 1998).

\subsection{Empirical Studies}

There is evidence from a number of studies that legal issues influenced the management of patients' records. According to Harman (2006) and Pozgar (2007) the understanding of legal issues will help the records managers to manage patients' records properly and raise the standard of health care. An investigation carried out by (Rhoad, 1983; Mnjaina, 2003; Millar, 2003) on records management found that records has a reliable, legally verifiable source of evidence for decisions, they are document compliance with laws, rules and procedures, therefore without a good records management in place all legislative laws will be worthless. A similar study by Wgeretal (2003) noted that health care organization rely on patients' records for sharing of knowledge, administrative and financial functions. Therefore organizations that manage records casually find it difficult to access and retrieve information when needed. In addition Weed (2006) and Harman (2008) states that the inefficiency of filing, maintenance and storage system can be costly in terms of wasted space and resources, therefore, making patients' records available for hospital use at the right time will depend on proper 
maintenance of patients' records. The Health Insurance Portability Accountability Act (1996) and Pozgar (2007) recognizes the imperfection in human nature, correct the moral behaviour of the records managers towards acceptable standard of care and the enforcement of the federal and state laws, policies and regulations on ethical and legal issues concerning management of patients' records. In another study conducted by Reinhart- Thompson et al (2005) on legal health records reveals that patients' records' serves as testimony in legal proceedings, the federal and state laws and accrediting body served as standard, defining patients records content, maintenance and documentation are necessary as legal health records because inaccurate and incomplete records show that no activity occur to patients if actionable in the court.

\section{Methodology}

This study was carried out at the Tertiary Hospitals, South-West Nigeria. A correlation survey research design was used and the population consisted of all the 282 records managers ( $43.9 \%$ male and $56.1 \%$ female, Mage $=38.3$ years, age range: $20-50$ years) in the 10 tertiary hospitals in South-West, Nigeria. Data generated through questionnaire were analysed using descriptive statistics and simple correlation analysis at 0.05 alpha level.

\section{Findings}

In order to have better understanding and views about the most important issues of this research, this section presents the research findings obtained from the record managers in Tertiary Hospitals, South-West Nigeria. The return rate of 282 copies of the questionnaire dispatched to the health record managers in the South-West Nigeria showed that 230 copies representing $81.6 \%$ were duly completed and returned while 52 copies representing $18.4 \%$ of the questionnaire were not duly completed. Therefore, the result presented in the following sections was based on the 230 copies of the questionnaire that were duly completed and returned. The analyses of the study were shown on Table 1 to 3 below.

Table 1: Ways to manage patients' records in tertiary hospitals

\begin{tabular}{|c|c|c|c|c|c|c|}
\hline $\begin{array}{l}\text { What are the ways to manage patients' records in } \\
\text { tertiary hospitals in South-West, Nigeria? }\end{array}$ & SA & A & $\mathrm{D}$ & SD & $\bar{X}$ & $\begin{array}{l}\text { Std. } \\
\text { D }\end{array}$ \\
\hline \multicolumn{7}{|l|}{ Records Creation } \\
\hline $\begin{array}{l}\text { Records creation requires the knowledge of patient's } \\
\text { personal information. }\end{array}$ & $\begin{array}{l}139 \\
60.4 \%\end{array}$ & $\begin{array}{l}65 \\
27.4 \% \\
\end{array}$ & $\begin{array}{l}25 \\
10.9 \% \\
\end{array}$ & $\begin{array}{ll}3 \\
1.3 \% \\
\end{array}$ & 3.47 & .74 \\
\hline $\begin{array}{l}\text { Capturing of patient's identification information } \\
\text { provides for accurate and reliable health information. }\end{array}$ & $\begin{array}{l}122 \\
3.0 \%\end{array}$ & $\begin{array}{l}64 \\
27.8 \%\end{array}$ & $\begin{array}{l}31 \\
13.5 \%\end{array}$ & $\begin{array}{ll}13 \\
5.7 \%\end{array}$ & 3.28 & .90 \\
\hline $\begin{array}{l}\text { Medical records are assigned hospital numbers for easy } \\
\text { retrieval. }\end{array}$ & $\begin{array}{l}107 \\
46.5 \%\end{array}$ & $\begin{array}{l}76 \\
33.0 \%\end{array}$ & $\begin{array}{l}43 \\
18.7 \%\end{array}$ & $\begin{array}{ll}4 \\
1.7 \%\end{array}$ & 3.24 & .82 \\
\hline $\begin{array}{l}\text { Records are created to provide evidence of patient } \\
\text { treatment in the hospital. }\end{array}$ & $\begin{array}{l}64 \\
43.9 \%\end{array}$ & $\begin{array}{l}71 \\
30.9 \%\end{array}$ & $\begin{array}{l}54 \\
23.5 \%\end{array}$ & $\begin{array}{l}4 \\
1.7 \%\end{array}$ & 3.16 & .85 \\
\hline $\begin{array}{l}X-\text { ray forms are created in paper and electronic forms } \\
\text { to detect site of injury in the body system. }\end{array}$ & $\begin{array}{ll}46 \\
20.0 \% \\
\end{array}$ & $\begin{array}{ll}171 \\
74.3 \% \\
\end{array}$ & $\begin{array}{ll}8 \\
3.47 \% \\
\end{array}$ & $\begin{array}{ll}5 \\
2.17 \% \\
\end{array}$ & 3.12 & 1.02 \\
\hline \multicolumn{7}{|l|}{ Records Maintenance } \\
\hline $\begin{array}{l}\text { Prompt retrieving of patient records for treatment } \\
\text { increase efficiency of the records manager. }\end{array}$ & $\begin{array}{l}74 \\
32.2 \%\end{array}$ & $\begin{array}{l}148 \\
46.1 \%\end{array}$ & $\begin{array}{l}5 \\
2.17 \%\end{array}$ & $\begin{array}{l}3 \\
1.30 \%\end{array}$ & $\begin{array}{l}3 . . \\
3.27\end{array}$ & .77 \\
\hline $\begin{array}{l}\text { Patient's records are processed and handled } \\
\text { confidentially. }\end{array}$ & $\begin{array}{l}68 \\
29.6 \%\end{array}$ & $\begin{array}{l}152 \\
66.1 \%\end{array}$ & $\begin{array}{l}7 \\
3.04 \%\end{array}$ & $\begin{array}{ll}3 \\
1.30 \%\end{array}$ & 3.24 & .92 \\
\hline $\begin{array}{l}\text { Updating of patient medical records forms and content is } \\
\text { necessary before patient treatment in the hospital. }\end{array}$ & $\begin{array}{l}78 \\
33.9 \%\end{array}$ & $\begin{array}{l}132 \\
57.3 \%\end{array}$ & $\begin{array}{l}12 \\
5.21 \%\end{array}$ & $\begin{array}{l}8 \\
3.47 \%\end{array}$ & 3.22 & .83 \\
\hline $\begin{array}{l}\text { Effective management of patient records are in line with } \\
\text { records life cycle model. }\end{array}$ & $\begin{array}{l}53 \\
23.04 \%\end{array}$ & $\begin{array}{l}161 \\
70 \%\end{array}$ & $\begin{array}{l}14 \\
6.08 \%\end{array}$ & $\begin{array}{l}2 \\
0.86 \%\end{array}$ & 3.15 & .84 \\
\hline $\begin{array}{l}\text { Straight numerical filing method increases } \\
\text { effectiveness of the medical record department. }\end{array}$ & $\begin{array}{l}45 \\
19.5 \% \\
\end{array}$ & $\begin{array}{l}158 \\
68.7 \%\end{array}$ & $\begin{array}{l}21 \\
9.13 \%\end{array}$ & $\begin{array}{l}6 \\
2.60 \%\end{array}$ & 3.05 & .85 \\
\hline $\begin{array}{l}\text { Patient records are maintained until it meets s the end of } \\
\text { its retention period. }\end{array}$ & $\begin{array}{l}58 \\
25.2 \% \\
\end{array}$ & $\begin{array}{l}144 \\
62.6 \% \\
\end{array}$ & $\begin{array}{ll}19 \\
8.26 \% \\
\end{array}$ & $\begin{array}{l}9 \\
3.91 \% \\
\end{array}$ & 2.90 & .86 \\
\hline \multicolumn{7}{|l|}{ Use of Health Records } \\
\hline Legal value is part of the beneficial effect of records. & $\begin{array}{ll}53 \\
23.04 \%\end{array}$ & $\begin{array}{l}147 \\
63.9 \% \\
\end{array}$ & $\begin{array}{l}23 \\
10.0 \% \\
\end{array}$ & $\begin{array}{ll}7 \\
3.04 \% \\
\end{array}$ & 3.06 & .04 \\
\hline $\begin{array}{l}\text { Preparation for clinical consultation involves the use of } \\
\text { medical records. }\end{array}$ & $\begin{array}{l}46 \\
20.0 \%\end{array}$ & $\begin{array}{l}157 \\
68.3 \%\end{array}$ & $\begin{array}{l}18 \\
7.83 \%\end{array}$ & $\begin{array}{l}98 \\
3.91 \%\end{array}$ & 3.04 & .95 \\
\hline $\begin{array}{l}\text { Me Medical records are kept for future purposes in the } \\
\text { hospital. }\end{array}$ & $\begin{array}{l}58 \\
25.2 \%\end{array}$ & $\begin{array}{l}134 \\
58.2 \%\end{array}$ & $\begin{array}{l}26 \\
11.30 \%\end{array}$ & $\begin{array}{l}12 \\
5.21 \%\end{array}$ & 3.03 & .92 \\
\hline $\begin{array}{l}\text { Use of records must be restricted to those who need it for } \\
\text { patient treatment. }\end{array}$ & $\begin{array}{l}54 \\
23.5 \% \\
\end{array}$ & $\begin{array}{ll}136 \\
59.1 \% \\
\end{array}$ & $\begin{array}{l}23 \\
10.0 \% \\
\end{array}$ & $\begin{array}{l}17 \\
7.39 \% \\
\end{array}$ & 2.99 & .81 \\
\hline \multicolumn{7}{|l|}{ Health Records Storage } \\
\hline Finance and technical problems prevent computerization & 91 & 116 & 13 & 10 & 3.30 & .99 \\
\hline
\end{tabular}




\begin{tabular}{|c|c|c|c|c|c|c|}
\hline of patients' records' & $39.6 \%$ & $\begin{array}{ll}5 \\
50.4 \% \\
\end{array}$ & $5.7 \%$ & $4.3 \%$ & & \\
\hline $\begin{array}{l}\text { In adequate storage space is one of the major problems } \\
\text { facing medical records manager. }\end{array}$ & $\begin{array}{l}66 \\
28.7 \%\end{array}$ & $\begin{array}{l}159 \\
69.1 \%\end{array}$ & $\begin{array}{l}3 \\
1.30 \%\end{array}$ & 2 & $\begin{array}{l}33 . \\
3.26\end{array}$ & .85 \\
\hline $\begin{array}{l}\text { Audit trails on the access and use of medical records for } \\
\text { easy tracking are maintained. }\end{array}$ & $\begin{array}{l}57 \\
24.7 \%\end{array}$ & $\begin{array}{l}160 \\
69.6 \%\end{array}$ & $\begin{array}{l}8 \\
3.47 \%\end{array}$ & $\begin{array}{l}5 \\
2.17 \%\end{array}$ & 3.17 & .92 \\
\hline $\begin{array}{l}\text { Sorting of patient records before filing will enhance } \\
\text { effectiveness. }\end{array}$ & $\begin{array}{ll}102 \\
44.3 \%\end{array}$ & $\begin{array}{ll}72 \\
31.3 \%\end{array}$ & $\begin{array}{l}46 \\
20.0 \%\end{array}$ & $\begin{array}{l}10 \\
4.3 \%\end{array}$ & 3.15 & .89 \\
\hline $\begin{array}{l}\text { Patient records are preserved for a short/permanent } \\
\text { duration }\end{array}$ & $\begin{array}{l}82 \\
35.7 \% \\
\end{array}$ & $\begin{array}{l}114 \\
49.6 \% \\
\end{array}$ & $\begin{array}{l}18 \\
7.8 \%\end{array}$ & $\begin{array}{l}16 \\
7.0 \% \\
\end{array}$ & 3.13 & .83 \\
\hline $\begin{array}{l}\text { In adequate filing shelve and cabinets for storing } \\
\text { patients' records prevent proper maintenance of } \\
\text { patients; records. }\end{array}$ & $\begin{array}{l}56 \\
24.3\end{array}$ & $\begin{array}{c}152 \\
66.1\end{array}$ & $\begin{array}{l}14 \\
6.1\end{array}$ & $\begin{array}{l}8 \\
3.47\end{array}$ & 3.11 & .94 \\
\hline $\begin{array}{l}\text { Reliable medical records storage and security control are } \\
\text { available in the hospital. }\end{array}$ & 53 & $65.7 \%$ & $\begin{array}{l}18 \\
7.8 \%\end{array}$ & $\begin{array}{c}8 \\
3.47 \%\end{array}$ & 3.08 & .85 \\
\hline $\begin{array}{l}\text { Medical records that are not needed for current business } \\
\text { of the hospital are preserved. }\end{array}$ & $\begin{array}{l}49 \\
21.3 \% \\
\end{array}$ & $\begin{array}{r}162 \\
70.4 \% \\
\end{array}$ & $\begin{array}{l}13 \\
5.7 \% \\
\end{array}$ & $6.60 \%$ & 3.08 & .79 \\
\hline \multicolumn{7}{|l|}{ Disposition of Health Records } \\
\hline $\begin{array}{l}\text { Dormant patient records are audited and transferred to } \\
\text { the medical archives. }\end{array}$ & $\begin{array}{l}63 \\
27.4 \% \\
\end{array}$ & $\begin{array}{r}152 \\
66.1 \% \\
\end{array}$ & $\begin{array}{l}11 \\
4.8 \% \\
\end{array}$ & $\begin{array}{l}4.74 \% \\
\end{array}$ & 3.17 & .88 \\
\hline $\begin{array}{l}\text { Semi-active patient records management procedure is in } \\
\text { place. }\end{array}$ & $\begin{array}{l}59 \\
25.7 \%\end{array}$ & $61.3 \%$ & $\begin{array}{l}17 \\
7.4 \%\end{array}$ & $\begin{array}{l}13 \\
5.7 \%\end{array}$ & 3.16 & .79 \\
\hline $\begin{array}{l}\text { Some inactive records hold historical value to the patient } \\
\text { and the hospital they are managed at medical records } \\
\text { centre. }\end{array}$ & $\begin{array}{l}58 \\
25.2 \%\end{array}$ & $\begin{array}{l}146 \\
63.5 \%\end{array}$ & $\begin{array}{l}17 \\
7.4 \%\end{array}$ & $\begin{array}{l}9 \\
3.91 \%\end{array}$ & $\begin{array}{l}3.1 \\
3.10\end{array}$ & .93 \\
\hline $\begin{array}{l}\text { Patients records centre management is in place in the } \\
\text { hospital. }\end{array}$ & $\begin{array}{l}57 \\
24.8 \% \\
\end{array}$ & $\begin{array}{l}145 \\
63.04 \% \\
\end{array}$ & $\begin{array}{l}17 \\
7.4 \% \\
\end{array}$ & $\begin{array}{l}11 \\
4.8 \% \\
\end{array}$ & 3.08 & .04 \\
\hline $\begin{array}{l}\text { Retention and disposition schedules are required in the } \\
\text { practice and management of patient records. }\end{array}$ & $\begin{array}{l}61 \\
26.52 \% \\
\end{array}$ & $\begin{array}{l}134 \\
58.2 \% \\
\end{array}$ & $\begin{array}{l}21 \\
9.1 \% \\
\end{array}$ & $\begin{array}{l}14 \\
6.1 \% \\
\end{array}$ & 3.05 & 1.06 \\
\hline $\begin{array}{l}\text { Current practices in the disposition of medical records } \\
\text { are followed. }\end{array}$ & $\begin{array}{l}51 \\
22.2 \% \\
\end{array}$ & $\begin{array}{l}149 \\
64.7 \% \\
\end{array}$ & $\begin{array}{l}20 \\
8.6 \% \\
\end{array}$ & $\begin{array}{l}10 \\
4.3 \% \\
\end{array}$ & 3.04 & .81 \\
\hline $\begin{array}{l}\text { There are plans to protect Occasionally used patient } \\
\text { records in the hospital. }\end{array}$ & $\begin{array}{l}55 \\
23.9 \%\end{array}$ & $\begin{array}{l}134 \\
58.2 \%\end{array}$ & $\begin{array}{l}29 \\
12.6 \%\end{array}$ & $\begin{array}{ll}12 \\
5.21 \%\end{array}$ & 3.00 & .77 \\
\hline $\begin{array}{l}\text { Policies guiding medical archives management are in } \\
\text { place }\end{array}$ & $\begin{array}{l}57 \\
24.8 \% \\
\end{array}$ & $\begin{array}{l}128 \\
55.6 \%\end{array}$ & $\begin{array}{l}33 \\
14.3 \% \\
\end{array}$ & $\begin{array}{l}12 \\
5.21 \% \\
\end{array}$ & 3.00 &. .87 \\
\hline $\begin{array}{l}\text { Records are disposed in other to conceal unethical } \\
\text { practices }\end{array}$ & $\begin{array}{l}23 \\
10 \%\end{array}$ & $\begin{array}{l}29 \\
12.6 \%\end{array}$ & $\begin{array}{l}106 \\
46.1 \%\end{array}$ & $\begin{array}{l}72 \\
31.3 \%\end{array}$ & 2.01 & .83 \\
\hline
\end{tabular}

Finding on the above Table 1 revealed the ways in which patients' records were managed in the tertiary hospitals in South-West, Nigeria through the process of records management life cycle; that is records creation, records maintenance, records use, records storage and disposition of patients' records. Out of the five stages of records management, the records managers paid much more attention to records creation, records storage and considerable actions was taken to ensure proper maintenance of patients' records in their health records departments, but less attention was paid to the use of patients' records and disposition of patients' records, because the records managers are rarely involved in using patients' records for publishing or conducting research to promote their work and profession. In the light of this, all phases of records management life cycle should be given equal attention and enough funds should be provided by the hospitals management for the computerization of patients' records, purchase of filing equipment for preservation and storage of patients' records' This finding is supported by Carter (2003) who in his study of use and maintenance of patients' records showed that the availability of patient's records for use at the right time depends on their proper management. Patients' records will be maintained as paper records or electronic health records, in accordance with the accrediting agency and professional regulations in order to serve the purpose of treatment, research, teaching, education and legal evidence.

Table 2: Existing legal practices in tertiary hospitals in Southwest Nigeria

\begin{tabular}{|c|c|c|c|c|c|c|c|}
\hline $\mathrm{S} \backslash \mathrm{N}$ & Existing legal practices in tertiary hospitals. & SA & A & $\mathrm{D}$ & SD & $\overline{\bar{X}}$ & Std.D \\
\hline 1 & $\begin{array}{l}\text { Government/Professional regulations support } \\
\text { health workers to patient in the hospital }\end{array}$ & $\begin{array}{l}104 \\
45.2 \% \\
\end{array}$ & $\begin{array}{l}81 \\
35.2 \% \\
\end{array}$ & $\begin{array}{ll}42 \\
18.3 \% \\
\end{array}$ & $\begin{array}{l}3 \\
1.3 \% \\
\end{array}$ & 3.24 & .79 \\
\hline 2 & $\begin{array}{l}\text { Legislative bills passed by the National or State } \\
\text { assemblies 'impact on the management of patient } \\
\text { records. }\end{array}$ & $\begin{array}{l}76 \\
33.0 \%\end{array}$ & $\begin{array}{l}125 \\
54.3 \%\end{array}$ & $\begin{array}{l}21 \\
9.13 \%\end{array}$ & $\begin{array}{l}8 \\
3.47 \%\end{array}$ & 3.16 & 1.09 \\
\hline 3 & $\begin{array}{l}\text { Government / professional regulations provide an } \\
\text { avenue to discipline medical records managers. }\end{array}$ & $\begin{array}{l}69 \\
30.0 \% \\
\end{array}$ & $\begin{array}{l}115 \\
50.0 \% \\
\end{array}$ & $\begin{array}{l}36 \\
15.7 \% \\
\end{array}$ & $\begin{array}{l}10 \\
4.3 \% \\
\end{array}$ & 3.08 & .79 \\
\hline 4 & $\begin{array}{l}\text { Health records managers must be familiar with the } \\
\text { laws guiding the practice of medical records in }\end{array}$ & $\begin{array}{l}66 \\
28.7 . \% \\
\end{array}$ & $\begin{array}{l}117 \\
50.9 \% \\
\end{array}$ & $\begin{array}{l}40 \\
17.4 \%\end{array}$ & $\begin{array}{l}7 \\
3.0 \% \\
\end{array}$ & 3.05 & .75 \\
\hline
\end{tabular}


Legal Issues in the Management of Patients' Records in Tertiary Hospitals in Nigeria

\begin{tabular}{|c|c|c|c|c|c|c|c|}
\hline & their environment. & & & & & & \\
\hline 5 & $\begin{array}{l}\text { Government policies do not support violation of } \\
\text { patient rights in the hospital. }\end{array}$ & $\begin{array}{l}48 \\
20.9 \%\end{array}$ & $\begin{array}{l}142 \\
61.7 \%\end{array}$ & $\begin{array}{ll}33 \\
14.3 \%\end{array}$ & $\begin{array}{l}7 \\
3.0 \%\end{array}$ & 3.00 & .69 \\
\hline 6 & $\begin{array}{l}\text { There is the need for uniform laws on health } \\
\text { records management that will cut across the three } \\
\text { tiers of government. }\end{array}$ & $\begin{array}{l}85 \\
37.0 \%\end{array}$ & $\begin{array}{l}91 \\
39.6 \%\end{array}$ & $\begin{array}{l}21 \\
9.1 \%\end{array}$ & $\begin{array}{l}33 \\
14.3 \%\end{array}$ & 2.99 & 1.02 \\
\hline 7 & $\begin{array}{l}\text { Medical records managers protects legal interest } \\
\text { of the patient in spite of government policy of free } \\
\text { treatment services }\end{array}$ & $\begin{array}{l}59 \\
25.6 \%\end{array}$ & $\begin{array}{l}120 \\
52.2 \%\end{array}$ & $\begin{array}{l}29 \\
12.6 \%\end{array}$ & $\begin{array}{l}22 \\
9.6 \%\end{array}$ & 2.94 & .82 \\
\hline 8 & $\begin{array}{l}\text { Medical records managers do not disregard } \\
\text { legislative laws affecting the management of } \\
\text { patient records. }\end{array}$ & $\begin{array}{l}66 \\
28.7 \%\end{array}$ & $\begin{array}{l}104 \\
45.2 \%\end{array}$ & $\begin{array}{l}38 \\
16.5 \%\end{array}$ & $\begin{array}{l}22 \\
9.5 \%\end{array}$ & 2.93 & 1.01 \\
\hline 9 & $\begin{array}{l}\text { Mutilation of patient records for study, teaching } \\
\text { and seminars affects the image of the patient and } \\
\text { causes civil liability. }\end{array}$ & $\begin{array}{l}64 \\
27.9 \%\end{array}$ & $\begin{array}{l}97 \\
42.1 \%\end{array}$ & $\begin{array}{l}54 \\
23.3 \%\end{array}$ & $\begin{array}{l}13 \\
5.7 \%\end{array}$ & 2.92 & .86 \\
\hline 10 & $\begin{array}{l}\text { Government policies in most cases are not } \\
\text { supported by the realities of the information on } \\
\text { ground. }\end{array}$ & $\begin{array}{l}58 \\
25.2 \%\end{array}$ & $\begin{array}{l}107 \\
46.5 \%\end{array}$ & $\begin{array}{l}52 \\
22.6 \%\end{array}$ & $\begin{array}{l}13 \\
5.7 \%\end{array}$ & 2.91 & .89 \\
\hline 11 & $\begin{array}{l}\text { Forging of medical certificate/sick leave in the } \\
\text { medical records management department affects } \\
\text { the management of patient records and is an illegal } \\
\text { act. }\end{array}$ & $\begin{array}{l}55 \\
23.9 \%\end{array}$ & $\begin{array}{l}113 \\
49.1 \%\end{array}$ & $\begin{array}{l}49 \\
21.3 \%\end{array}$ & $\begin{array}{l}13 \\
5.7 \%\end{array}$ & 2.91 & .82 \\
\hline 12 & $\begin{array}{l}\text { Copying and selling of patient records document } \\
\text { for monetary value are not common, the act is } \\
\text { criminally liable. }\end{array}$ & $\begin{array}{l}58 \\
25.2 \%\end{array}$ & $\begin{array}{l}108 \\
47.0 \%\end{array}$ & $\begin{array}{l}46 \\
20.0 \%\end{array}$ & $\begin{array}{l}18 \\
7.8 \%\end{array}$ & 2.90 & .87 \\
\hline 13 & $\begin{array}{l}\text { Backdating doctor's signature to avoid criminal } \\
\text { liability is against professional practice codes and is } \\
\text { punishable in the court. }\end{array}$ & $\begin{array}{l}46 \\
20.0 \%\end{array}$ & $\begin{array}{l}121 \\
52.6 \%\end{array}$ & $\begin{array}{l}46 \\
20.0 \%\end{array}$ & $\begin{array}{l}17 \\
7.4 \%\end{array}$ & 2.85 & 1.01 \\
\hline 14 & $\begin{array}{l}\text { Failure of the medical records managers to attend to } \\
\text { patient on time contravenes the duty of care and } \\
\text { is liable. }\end{array}$ & $\begin{array}{l}64 \\
27.8 \%\end{array}$ & $\begin{array}{r}119 \\
1.7 \%\end{array}$ & $\begin{array}{l}20 \\
8.7 \%\end{array}$ & $\begin{array}{l}27 \\
11.7 \%\end{array}$ & 2.85 & .97 \\
\hline 15 & $\begin{array}{l}\text { Federal and State laws provide a benchmark for the } \\
\text { management of patient records. }\end{array}$ & $\begin{array}{l}49 \\
21.3 \%\end{array}$ & $\begin{array}{l}118 \\
51.3 \%\end{array}$ & $\begin{array}{l}40 \\
17.4 \%\end{array}$ & $\begin{array}{l}23 \\
10 \%\end{array}$ & 2.84 & .89 \\
\hline 16 & $\begin{array}{l}\text { Abuse of Federal and State laws by releasing } \\
\text { patient records without the consent of the patient } \\
\text { may cause litigation. }\end{array}$ & $\begin{array}{l}47 \\
20.4 \%\end{array}$ & $\begin{array}{l}125 \\
54.34 \%\end{array}$ & $\begin{array}{l}31 \\
13.47 \%\end{array}$ & $\begin{array}{l}27 \\
11.7 \%\end{array}$ & 2.83 & .94 \\
\hline
\end{tabular}

Finding of Table 2 revealed that government/professional regulations, legislative bills passed by the National and State assemblies, federal and state laws provided benchmark for measuring progress concerning patients' records management and government policies on violation of patients' rights. These legal issues are evident to show that legal considerations existed in tertiary hospitals in South-West, Nigeria. This finding is supported by Hughes (2002) where it was revealed that hospitals cannot operates without a license and any hospital that violates the standard of care may lose it license or be penalized. Another observation by MC Way (2012) supported that legislative branch determines the modification of pre- existing law and the judiciary branch interprets the law through adjudication and resolution of dispute. This finding is also supported by Pozgar (2007) and Joint Commission on Accreditation (2008) which revealed that the records managers must understand all the statutes that affect the creation and maintenance of agencies and laws that regulate hospitals.

\section{Hypothesis Testing}

There is no significant relationship between Legal issues and the management of patients' records in tertiary hospitals in South-West Nigeria.

Table 3: Correlation Analysis of Management of Patients' Records and Records Managers' Legal issues

\begin{tabular}{|l|l|l|l|l|l|l|}
\hline Variable & Mean & Std. Dev. & $\mathrm{N}$ & $\mathrm{R}$ & $\mathrm{P}$ & Remark \\
\hline $\begin{array}{l}\text { Management of Patients' Records } \\
\text { Legal Issues }\end{array}$ & 66.9957 & 12.8306 & & & & \\
& 34.4217 & 5.7655 & 230 & .418 & .000 & Sig. \\
\hline
\end{tabular}

Table 3present the correlation analysis of records managers' legal Issues and the management of patients' records in tertiary hospitals in South-West, Nigeria. The result reveals a positive significant relationship between records managers' legal issues and management of patients' records $(r=.418, N=230, P$ $<.0 .05)$. Statistically, the null hypothesis was rejected meaning that there was a significant positive relationship between records managers' legal issues and the management of patients' records in tertiary hospitals in SouthWest, Nigeria. This result is in consonance with Joint Commission on Accreditation (2008) which stated that the records managers must understand all the statutes that affect the creation and maintenance of agencies and laws that regulate hospitals. 


\section{Conclusion And Recommendations}

The efficient management of patients' records by records managers relies extensively on the extent to which legal issues. Legal practice emphasizes the practical regulation of morality or behaviour and deals with the inadequacies and imperfections in human nature. Therefore, without a proper records management in place with proper and adequate legal issues employed in the management of patients' records in Nigerian tertiary hospitals the standard of management of patients' records will be worthless. Therefore, legal considerations are very important in Nigerian hospitalsto avoid releasing patients' records to a wrong party that may use the information against the patient's consent.In few of the above findings, the study recommended that federal government should promulgate law on management of patients' records that will cut across the federal, state and local government so as to provide uniform practice and enhance good standard of records management practice. Also, Nigerian courts of Justice should ensure that cases on unethical and illegal issues among health records managers are treated in time so as to avoid adjournments. Finally, violators of rules concerning patients' records and rights of privacy abuses should be made to face the wrath of the law, so as to serve as deterrent to others.

\section{References}

[1]. Akanji, D.O.(2010). Health Records Management in Nigeria: The Journey So Far Nigeria, Royal Publisher Benin.

[2]. American Health Information Management Association (2011).Health Information Management, Concepts, Principle and Practice U.S.A. Illinois: Pub.

[3]. American Health Information Management Association (2000).Consent For Use And Disclosure of Information. Journal Of AHIMA $72(5) ; 64-64$

[4]. Benjamin, B. (2001).Medical Records Pub. London: Willian Heinemann Medical Book Limited.

[5]. Bloomrosen, M. (2006).e-Him.information technology and information exchange: Ethical challenges in the management of health information. $2^{\text {nd }}$ Ed. London: Oxford University Press.

[6]. Cater, P. (2003).Health Insurance Portability Analysis Act, Compliance Handbook.Frederick, M.D Apen Publishers.

[7]. Cohen, M.R. and Amatayakul, M. (2004).Segmenting the EHR Market. USA: Advance for Health Information.

[8]. Dicks, R.S. and Sten, E.B. (2001). The Computer Based Patient Records: An Essential Technology for Health Care. Revised Ed. Washington D.C: National Academic Press.

[9]. Goodman, W. (1998)..Ethics, computing and medicine: Informatics and the transformation of Health Care. USA: Cambridge University Press.

[10]. Harman, L. (2006).Ethical challenges in the management of health information. $2^{\text {nd }}$ Ed Sudblury M.A Jones and Bartlett.

[11]. Hugh, R. (2005). Electronic Health Records: Clinical Information Systems \& Health Record Management Information Retrieved from:https://www.accenture.com.sa/Global/Services/Byindustry/Health_and_Life_Sciences/Providers_and_Government_Health/R_ andI/electronIchealhaccenture.htm. Accessed on 2/8/2013

[12]. Huffman, E. (1994).Health Information Management: Physician's Records Company, Illinos, 780.

[13]. Hughes, G. (2002). Destruction of Patient Health Information.Journal of AHIMA. 68(5)37-40.

[14]. Hughes, G. (2002). Laws and Regulation Governing The Disclosure of Health Information. Journal of AHIMA 72(5) 64-64.

[15]. Institute of Medicine (2001).Committee on Quality of Healthcare in America.Cross the Quality Clasm: A New Health System for the 21st Century. Washington D.C.: National Academy Press.

[16]. Joint Commission Accreditation (2009).Comprehensive Accreditation Manual For Hospitals, New York: Oakbrook Terrace Press.

[17]. McWay D.C. (2012).Legal Aspects of Health Information Management.NewYork: Delmar Publishing, Clifton.

[18]. Millar, I. (2003). The Right Information - The Right to Records. The relationship between records keeping, Access to Information and Government Accountability. AfrJ.Lib., 19 (3) 183-188

[19]. Mnjana, N.M. (2003). Records Management and freedom of information A marriage partnership information development. Afr. $J$. Lib. Arch. \& inf. Sc. Vol. 19(3); 1466-147016.

[20]. Pozgar, G.D. and Pozgar, N.S. (1996). Legal aspects of health care administration. Retrieved from: http://cbaccccb.ic.gc.ca/epic/site/cbaccccb.nsf/en/ah00514e.html.Accessed on Feb 10, 2013.

[21]. Pratt, P.H. and Adam S. (2008).Concept of Data Management $6^{\text {th }}$ Ed. Cambrigde.

[22]. Rhoads, B.J. (1983).The Role of Archives and Records Management in National Information Systems. Paris: ARAMP Study.

[23]. Rhodes, H. (2000).Redisclosure of Patient Health Information Management Operation.Journal of AHIMA 74(4) 56.

[24]. Rhodes, H. (2000).Retention of Health Information.Journal of AHIMA, 24.

[25]. Rinehart Thompson, L.A (2008). Perspectives in Health Information Management., ..........55 (9);1-3.

[26]. Rob, P. and Coronel, C. (2009).Database System: Design Implementation and Management $8^{\text {th }}$ Ed. Boston. M .A

[27]. Rotich, J.K. (2003). Installing and implementing a computer-based patient record system in sub-Saharan Africa: the Mosoriot Medical RecordSystem. J Am Med Inform Assoc, 2003;10 (4):295-303.

[28]. Schellenberg, T.R. (1998).Modern archives: Principles and techniques (Repr. ed.). Chicago: SAA

[29]. Shepard, E. and Yeo, G. (2003).Managing records a handbook of principles and practice. London: Facet Publishing.

[30]. Weed, L. (2008)..Medical Records, Medical Education and Patient Care. New York: Cleveland, Western Reserve University.

[31]. Yuan, Y. (2001). Privacy Protection in Electronic Commerce: A Theoretical Framework. Human System Management. McMaster Univ. Ontario. Canada. 20(1); Pp; 149-160. 